\title{
DEVELOPING THE CADETS' COMMUNICATION COMPETENCE FROM AN INTERCULTURAL PERSPECTIVE
}

\author{
Brândușa-Oana NICULESCU \\ "Nicolae Bălcescu" Land Forces Academy, Sibiu, Romania \\ branducosma@yahoo.com \\ Georgeta OBILIȘTEANU \\ "Nicolae Bălcescu" Land Forces Academy, Sibiu, Romania \\ pusa_obi@hotmail.com
}

\begin{abstract}
Traditionally, foreign language classes provide a systematic presentation and acquisition of knowledge and skills under the guidance and monitoring of a teacher. However, language is unquestionably related to culture. Being competent in a foreign language requires not only possessing the linguistic competence, but also understanding the culture that has defined and shaped it. The process of learning a foreign language involves an awareness of the culture of the target language, as well as the way it relates to one's own culture. This paper aims, first, to deal with major issues in the foreign language classes related to creating the conditions for students to acquire and develop the skills necessary to cope with the difficulties of the intercultural situations, and second, to determine the culture-related content areas and give practical tips for teachers to employ in preparing their students for the intercultural challenge. It also points to the important role of teachers in conceiving and producing the teaching-learning resources that will enable students to gain the relevant cultural background knowledge and skills, as well as to the benefits of using culture-focused activities along with the grammarbased tasks.
\end{abstract}

KEYWORDS: teaching materials, intercultural communicative competence, activity types, attitudes, skills

\section{Introduction}

The aim of foreign language education of preparing competent communicators in intercultural situations demands foreign language educators to promote intercultural communication and the understanding of cultural differences in the foreign language classes. The close relationship between foreign language teaching and intercultural communication must be emphasized. If cultural information is not taught as part of developing the communicative competence, complete communication may not take place, or misunderstandings may occur. Teaching culture in foreign language classes is imperative in order to avoid miscommunication.

In designing the curriculum and syllabus, foreign language educators need to incorporate the development of the intercultural communicative competence in 
order to assist students to gain awareness of the target language culture, an appreciation for their own culture, and the enhancement of the abilities that will enable them to be successful communicators in intercultural situations. The concept of culture has become the focus of foreign language teaching and learning only in the last few years. It does not refer to simply conveying facts and figures about the foreign language culture, it means creating the appropriate conditions for learners to understand and perceive everything from a comparative perspective.

Thus, this shift of dominance from the linguistic competence to the intercultural communicative competence has made the curriculum planners and syllabus designers establish not only linguistic outcomes for students to achieve, but also cultural ones (Tuna \& Razi, 2016). The more compelling importance of culture in the foreign language curriculum and syllabus emphasize the necessity to find the appropriate combination of linguistic and cultural elements, the activity types and strategies to be used in developing the intercultural communicative competence.

\section{Competence}

2. Intercultural Communicative

Providing a definition of intercultural communication competence is not an easy undertaking. In the last 30 years, scholars have not fully agreed on a proper definition. However, in a study in 2004, Deardorff (p. 194) pointed out that intercultural scholars commonly accepted to define it as "the ability to communicate effectively and appropriately in intercultural situations based on one's intercultural knowledge, skills, and attitudes". She also noticed that, for pedagogical purposes, Byram's definition is regarded as highly suitable among educators. Byram's Model of Intercultural Competence (1997) identifies a combination of three components any foreign language speaker should have to be interculturally competent: knowledge, attitudes and skills.
Byram (1997) and Byram et al. (Byram, Gribkova, \& Starkey, 2002) use the term knowledge to refer to the awareness of one's own and the target language cultures, as well as awareness of how the perception of other groups is conditioned by our own cultural framework. In order to challenge stereotypes and prejudices about other cultures, foreign language learners should also possess attitudes of tolerance, respect and openness towards members with different cultural backgrounds, along with the willingness to communicate and establish relationships with them. The term skills refers to the abilities to discover and acquire new cultural knowledge, as well as to the abilities of interpreting and relating behaviors, norms or beliefs from other cultures with those of our own.

It is worth mentioning that recognized institutions such as the Council of Europe and publications such as the "Common European Framework of Reference for Languages" (https://www.coe.int/t/dg4/ linguistic/source/framework_en.pdf) have highlighted the vital importance of establishing intercultural communication competence as a major goal of language education, along with the linguistic competence. This is a requirement that the current education must meet in order to cope with the challenges of a more and more diverse cultural environment in which intercultural encounters regularly take place. By raising the citizens' awareness on the value of cultural diversity, tolerance and mutual understanding, the coexistence and communication among people of different cultural orientations that live in the same space is facilitated.

According to Fox (2015), in achieving intercultural communicative competence, it is also obligatory to master the norms of a society, the unspoken rules describing certain behavior as being acceptable or unacceptable, and its traditions. The way a learner uses his 
linguistic potential depends on the learner's socio-cultural knowledge. It is generally acknowledged that if an individual does not have the social and cultural background information related to the foreign language, he/she is not able to use the foreign language properly and be a competent intercultural communicator. Intercultural communicative competence also implies knowledge of several aspects of culture and society: forms of introduction and salute, social practices, choices of register and style, beliefs, attitudes, perceptions, expectations, etc. To be a fruitful interlocutor in intercultural situations, linguistic as well as cultural competences are necessary.

With regard to the above definitions, Byram (2008, p. 78) describes an intercultural communicator thus:

"The intercultural speaker is someone who is aware of cultural similarities and differences, and is able to act as mediator between two or more cultures, two or more sets of beliefs, values and behaviours. The intercultural speaker is not someone who is bicultural, someone who can pass as belonging to two cultural groups. This is a matter of circumstances, of being brought up in a situation where identifying with the values, beliefs and behaviours of two groups is an option or even a necessity. Bicultural people are not necessarily able to act interculturally as they may not be conscious of the two cultures in which they live and the relationships between them. Acting interculturally presupposes that one is aware of difference and similarity and can decentre in order to help others to act together - or indeed to act oneself with others - in ways that overcome obstacles of difference".

\subsection{Effective Intercultural \\ Communication}

The ability needed to interact effectively and appropriately with members of different cultures also includes several attitudes. Effective intercultural communication requires (Byram, Gribkova, \& Starkey, 2002):
- empathy - an understanding of other people's behaviors and ways of thinking;

- respect - genuine appreciation of different ways of thinking and communication;

- motivation - source of a person's desire to foster intercultural relationships;

- tolerance - the ability and willingness to accept and acknowledge different behaviors and ways of thinking, the existence of opinions or behaviors that one does not necessarily agree with;

- tolerance for uncertainty - an individual's attitude about and level of comfort in handling uncertain situations, willingness to take risks;

- curiosity - willingness to discover other social and cultural practices;

- sensitivity - the awareness and responsiveness to other people's behaviors and ways of thinking;

- flexibility - willingness to change and adapt to different ways of thinking;

- openness - willingness to accept other people's behaviors and ways of thinking.

By fostering attitudes that motivate learners to come into contact and grasp a different culture, teachers motivate them to discover knowledge that is relevant about that culture and develop the skills that will later enable them to successfully interact with individuals coming from that culture.

\section{Intercultural Communication within the Foreign Language Classes}

Culture is a vital part of the communication process. Therefore, since speakers of a different language "think differently when speaking” (Kramsch, 2004), teachers must incorporate culture in teaching the target language. In order to assist their students in using the target language more successfully and becoming efficient communicators, foreign language teachers have to deal with the cultural aspects of the foreign language being taught.

The culture-based activities designed by the teacher working with a certain group 
of students cannot be approached if they do not have the necessary cultural background knowledge. This knowledge allows them to broaden their horizons and comprehend the ideas they encounter in the authentic reading passages (excerpts from newspapers or books) or while listening to genuine tape recordings (taken from TV news bulletins or programs), and so see things from another viewpoint. Grammar-based tasks should be accompanied by culture-focused exercises so that students can develop the intercultural communication competence.

Exploiting culture-related tasks in the process of learning a foreign language is beneficial both for the students and for the teachers. If these activities are used in the process of learning, students consider classes more challenging, motivating them to actively participate and express opinion on various issues. If the content of language teaching is supported by the exploitation of the cultural elements, it becomes more meaningful.

In this context, the content of the teaching-learning resources is of major importance. It should help learners to become successful intercultural communicators. The didactic materials should be designed in such a way as to encourage students to reflect on their own culture in relation to others and become aware of the cultural values underlying the target language.

\subsection{Activity Types}

There is a wide range of activities to be didactically exploited in developing the learners' intercultural communication competence, such as audio- or video-taped cultural dialogues, recorded interviews with native speakers, written texts including information on the culture of the target language, simulation tasks and role plays requiring to adapt to authentic communication situations that might occur in real life crosscultural settings.

It is obvious that the teaching-learning resources have a major role to play.
The students' acquisition of the different aspects of intercultural communication competence from the teaching materials like course/textbooks or student's workbooks is based on the high responsibility of the teaching materials writers. The order in which students deal with the different aspects of the foreign language culture depends on the competence of all the educators involved in the teaching process, from curriculum planners, syllabus designers to teaching materials writers.

The content areas to deal with in the teaching materials that intend to develop intercultural communication competence could include: the social practices, customs and lifestyle of the target language culture; similarities and differences in values, beliefs and norms existing in the two cultures; the nature and dangers of stereotyping; non-verbal communication and proxemics; attitudes of openness, curiosity, empathy and non-judgmental thinking; useful communication strategies in intercultural settings.

The activities meant to develop this competence must enable students to explore their previous assumptions, experience and knowledge and compare them with the background information related to the foreign language culture.

Based on our own teaching experience, we recommend the following types of activity:

- brainstorming (to find out what learners have in mind about certain issues);

- short presentations (to familiarize learners with the history, customs, traditions and lifestyles of the target language and provide input for further discussion);

- listening to an audio-taped material or watching a video-taped material (to expose learners to authentic usage of target language and better understand the differences between his own culture and that of the foreign culture); 
- reading authentic materials (to gain a perspective through comparison between the two cultures);

- role plays and simulations (to realize what it is like to interact with people from another culture);

- quizzes (to provide learners with concrete information about a different culture and thus motivate them to get involved in purposeful debates held in small groups or with the whole class);

- discussions (to build competencerelevant attitudes and skills);

- portfolios (to take a critical stance and reflect on their own learning and intercultural experiences in the foreign language classroom and to raise their awareness on what they are capable or are not capable to do in intercultural situations).

These tasks should then be followed by pair or small group discussions or debates with the whole class so that students can clarify their attitudes, perceptions, towards the issues brought up into discussion.

\section{The Role of Foreign Language Teachers in Developing Cadets' Intercultural Communication Skills}

Defining the teacher's and the learners' role is of great importance. One the most remarkable hallmarks of intercultural education in foreign languages is the change from traditional roles assigned to teachers and learners to ones that are more in line with contemporary communicative language pedagogy.

Learners are no longer considered language students, but 'communicators' (Ellis \& Shintani, 2014) in the language they are learning. Moreover, they assume varying degrees of responsibility and autonomy in the performance of the tasks depending on their language proficiency in the target language or the task requirements. At the same time, foreign language educators are no longer understood as mere bearers of knowledge, but rather as 'facilitators' of the learning process, monitoring and supervising the learners' task performance, as well as guiding them in the intercultural exploration that encourages and motivates learners to engage in the discovery, analysis and reflection of interculturality (Moeller \& Nugent, 2014).

Although the culture language teaching approach is now widely recognized, little is actually known about what teachers understand by it and how to implement it in the classroom. There are various interpretations concerning the choice of the content areas to be tackled and the strategies to be used. At the same time, many teachers do not know how to set about improving their teaching in order to incorporate culture-based activities in their classes. They continue to use traditional materials that are not communicativeoriented in nature. Consequently, they cannot alter their own teaching style and act as aides for their learners' selfdevelopment. Teachers of foreign languages have to equip themselves with new methods and strategies.

Culture teaching should not be confined solely to imparting facts about the target language culture. What is more, learners are assumed to possess the necessary competence for intercultural encounters, once they get to know this concrete information. Unfortunately, many teachers tend to believe that if culture-related information is offered to cadets, their intercultural ability will be increased together with the progress they make in the linguistic development. Such a point of view could not be more misleading in the process of teaching and learning a foreign language.

In a civilian as well as in a military environment, instead of conveying mere knowledge, teachers should provide students with the opportunities to explore relevant cultural information, allowing them to discover, analyze and identify themselves the similarities and differences 
between their own culture and that of the target language. Comparing the two cultures would encourage learners to reflect on their own culture and gain a larger perspective from which to view the foreign one.

This approach could be a helpful and exciting way of understanding a new culture. Without the culture background information, the vocabulary and grammar patterns are likely to be meaningless, making classes boring and unchallenging.

Furthermore, the manner in which testing is done indicates that culture is not properly paid attention to. Both the progress and the achievement tests are focused on the knowledge the learners have acquired on the target language culture, not demanding them to comprehensively compare and contrast the two cultures, to make judgments and express opinions on the cultural topics. The tasks designed for assessing the students' achievement and the attainment of objectives must be realized in such a manner as to require cadets to infer the implied meaning in written texts, to practice reasoning and negotiation of meaning, to transfer information and to think creatively.

In pedagogical terms, it is obvious that the integration of culture in foreign language education requires a major reconsideration of syllabus design and teaching materials writing in that the former should involve culture-based tasks for teachers to design and the latter cultureoriented outcomes for students to achieve.

\section{Conclusion}

Language and culture are inextricably linked. The foundation of communication is represented by culture since language is meaningless without the cultural background against which it is spoken. In the teaching of foreign languages, the vocabulary and grammar patterns should be presented together with content related to the culture of the target language in order to shape learners' intercultural communicative competence. Foreign language teachers should be culture teachers. As learners acquire the target language, they learn about culture. In learning to use the foreign language, they learn to communicate with individuals from another culture. The problem is that mastering the lexis and grammar patterns does not automatically lead to a person's communicative competence in an intercultural context. Misunderstandings and even conflicts may appear in communication as a result of a lack of intercultural communication competence of the interlocutors. The ability to successfully communicate with individuals having a different cultural background depends not only on the linguistic performance an individual has attained, but also on the understanding of the beliefs, values and norms they hold, cherish and respect in the society they come from. A shift has to be made in the teaching of foreign languages towards the cultivation of intercultural communicative competence.

\section{REFERENCES}

Byram, M. (1997). Teaching and Assessing Intercultural Communicative Competence. Clevedon, UK: Multilingual Matters Ltd.

Byram, M. (2008). From foreign language education to education for intercultural citizenship: Essays and reflections. Clevedon, UK: Multilingual Matters Ltd.

Byram, M., Gribkova, B., \& Starkey, H. (2002). Developing the Intercultural Dimension in Language Teaching: A Practical Introduction for Teachers. Strasbourg: Council of Europe, Language Policy Division. Available at: https://www.coe.int/t/dg4/ linguistic/source/guide_dimintercult_en.pdf. 
Deardorff, D.K. (2004). The Identification and Assessment of Intercultural Competence as a Student Outcome of International Education at Institutions of Higher Education in the United States. (Unpublished dissertation). Raleigh, North Carolina: North Carolina State University. Available at:https://repository.lib.ncsu.edu/handle/1840.16/5733

Ellis, R., \& Shintani, N. (2014). Exploring Language Pedagogy through Second Language Acquisition Research. London and New York: Routledge Francis and Taylor Group.

Fox, A. (2015). Integrating ICT in the Language Classroom: An Intercultural Journey? In M.A. Vyas, \& Y.L. Patel, (Eds.), Teaching English as a Second Language: a New Pedagogy for a New Century, (Second Edition) (pp. 69-86). Delhi: PHI Learning Private Limited.

Kramsch, C. (2004). Language, thought, and culture. In A. Davies \& C. Elder (Eds.), The Handbook of Applied Linguistics (pp. 235-261). Oxford: Blackwell Publishing.

Moeller, A.J., \& Nugent, K. (2014). Building intercultural competence in the language classroom. In Stephanie Donau (ed.), Unlock the Gateway to Communication (pp. 1-18). Central States Conference Report, Eau Clarie, WI: Crown Prints. Available at: https://digitalcommons.unl.edu/teachlearnfacpub/161

The Common European Framework of Reference for Languages: Learning, Teaching, Assessment. Modern Languages Division, Strasbourg: Cambridge University Press. Available at: https://www.coe.int/t/dg4/linguistic/source/framework_en.pdf

Tuna, Ö.K., \& Razi, S. (2016). Integrating Culture into ELT Classes: What, Why and How?. Procedia - Social and Behavioral Sciences, 232, 41-48. 